\title{
Ecological Change Detection in Northeastern Bamenda Highlands, Cameroon, Based on Spatio-temporal Normalized Difference Vegetation Index (1979-2020)
}

\author{
Josephine A. Maghah, Cornelius M. Lambi, and Titus F. Ambebe
}

\section{ABSTRACT}

\begin{abstract}
Mountains are amongst the landforms that have undergone the most transformation. Landscape changes in mountains are driven by anthropogenic stressors and climatic change. The UN Sustainable development Goal 15 recognized the importance of conservation of mountain ecosystems for an enhancement of sustainable development. This study seeks to evaluate spatio-temporal ecological changes in the Northeastern Bamenda Highlands, based on a remote sensing-derived mountain green cover index proxy, the Normalized Difference Vegetation Index (NDVI). The study showed vegetation greening and browning trends exemplified by degraded montane forest linked to anthropogenic stressors and natural climatic shift. These anthropogenic stressors include deforestation, conversion of forest to farmlands and eucalyptus plantations, and the unsustainable grazing with inter-annual use of fires for pasture regeneration. As a means to ensure future ecological services provision of these highlands, landscape restoration strategies are needed. The greening of the highlands with water retaining trees species, sustainable grazing and farming restrictions in protected areas and its buffers.
\end{abstract}

Keywords: Change detection, Normalized Difference Vegetation Index, Mountain Green Cover Index, Forest loss, Ecological transformation, Urbanization.
Published Online: July 05, 2021

ISSN: $2684-446 \mathrm{X}$

DOI :10.24018/ejgeo.2021.2.4.144

\section{J. A. Maghah*}

Department of Geography and Planning, Faculty of Arts, The University of Bamenda, Cameroon.

(e-mail: akenjitulis@gmail.com)

C. M. Lambi

Department of Geography, University of Buea, Cameroon.

T. F. Ambebe

Department of Forestry and Wildlife Technology, College of Technology, The University of Bamenda, Cameroon.

*Corresponding Author

\section{INTRODUCTION}

Ecological processes are vital for maintaining life within the earth's ecosystem. Land cover and its temporal dynamics play a major role in global patterns of climate and biogeochemical cycles [1]. Increasing human activities have caused significant global ecosystem disturbances at various scales. There is an increasing need for effective techniques to quantify and detect ecological changes [2]. The transformation of natural landscapes and its replacement with humanized forms and anthropogenic systems has resulted in disequilibrium in most natural ecosystems with far reaching repercussions on ecosystem services provision and the global climatic system. One most common for ecological dynamics is land cover/use changes. The indicators frequently monitored via change detection include land use/land cover, disturbance, and phenology [3].

Monitoring the locations and distributions of land-cover changes is important for establishing linkages between policy decisions, regulatory actions, and subsequent landuse activities [4]. Long-term change detection results can provide insight into the stressors and drivers of change, potentially allowing for management strategies targeted toward cause rather than simply the symptoms of the cause [5]. Classifying and mapping vegetation is an important technical task for managing natural resources as vegetation provides a base for all living beings and plays an essential role in affecting global climate change [6], [7]. Remote sensing provides a broad view of landscapes and can be consistent through time, making it an important tool for monitoring and managing protected areas [6]. Remote sensing imagery offers unique possibilities for spatial and temporal characterization of the changes [8]. Remote sensing can serve as a measurement surrogate of spatial changes in ecological conditions [2].

For the 2030 Agenda, the UN established its Sustainable Development Goal 15 aimed to "Protect, restore and promote sustainable use of terrestrial ecosystems, sustainably manage forests, combat desertification, and halt and reverse land degradation and halt biodiversity loss". Sustainable Mountain Development is also the subject of Chapter 13 of Agenda 21, which notes that mountains are an important source of water, energy, biological diversity, minerals, forest products and agricultural products. They also provide ample recreational activities. Mountain environments represent major ecosystems which are essential to the survival of the global ecosystem, but they are rapidly changing [9]. Mountains supply more than half of humankind with water and are reservoirs for food, energy, and biodiversity [10]. Ecosystem services provided by mountains in general and mountain forests in particular also contribute to the welfare of people beyond mountains. For example, they regulate the quality and quantity of up to $80 \%$ of drinking water originating from the mountains and are 
hotspots of biodiversity [11]. Mountains host approximately 25 percent of terrestrial biodiversity as well as vital genetic resources for key crops and livestock. Changes in land use and climate are seriously threatening this global asset [10]. The transformation of mountainous landscapes mostly driven by anthropogenic stressors and climate change is increasing food insecurity and the vulnerability of mountain populations. According to FAO [10], mountain peoples are among the world's poorest in developing countries, a vast majority live below the poverty line and an estimated 300 million are food insecure and malnourished. To ascertain the importance of mountain ecosystems in sustaining livelihoods, the UN set its indicator 15.4 that stipulates that 'by 2030, all nations should ensure the conservation of mountain ecosystems, including their biodiversity, in order to enhance their capacity to provide benefits that are essential for sustainable development' through coverage by protected areas of important sites for mountain biodiversity (sub-indicator 15.4.1) and boosting the greenness of mountainous areas (15.4.2;). As a means to assess the ecological health of mountainous areas, sub-indicator 15.4.2 was recommended by the United Nations. The "Mountain Green Cover Index" (MGCI) measures changes of the green vegetation in mountain areas - i.e., forest, shrubs, trees, pastureland, cropland - to provide an indication of the status of conservation of their environment [12]. It is therefore against this backdrop that the study seeks to assess ecological changes over the northeastern Bamenda Highlands under the threat of landscape transformation, uncontrolled urban expansions, unsustainable land use practices and land cover/use changes. This data generated will guide stakeholders in putting in place landscape restoration strategies for a sustained provision of ecosystem services.

\section{MATERIALS AND METHODS}

\section{A. The Study Area}

Located in the Western Highlands of Cameroon, the Bamenda Highlands is enclosed along the Cameroon Volcanic Line. Its Northeastern portion overlooks the town of Bamenda within latitudes $5^{\circ} 48^{\prime} 0^{\prime \prime}$ and $6^{\circ} 0^{\prime} 0^{\prime \prime}$ North and longitude $10^{\circ} 30^{\prime} 0^{\prime \prime}$ and $10^{\circ} 21^{\prime} 0^{\prime \prime}$ East of the Greenwich Meridian (Fig. 1). Rising urban expansion is threatening the land cover of the study area. The forest cover now principally in patches provides the fuel wood needs of the nearby Bamenda Metropolis among other uses. The highlands presence in the form a coliseum being and major geo-hydrological divide for streams and their drainage basins (Fig. 1).

\section{B. Remote Sensing Vegetation Index}

During the last 10 years, scientists have made significant advances in modelling environmental dynamics [13], mostly geomatic techniques. Remote sensing allows for cost- and time-efficient monitoring of landscapes vital to the conservation of natural resources, ecosystems, and biodiversity [3]. Vegetation cover change detection is essential for a better understanding of the interactions and inter-relationships between humans and their ecosystem [14]. Remote sensing provides fast and robust methods to rapidly assess landscape ecological changes based on spectrally- derived vegetation indices. A number of remote sensing indices have been created to quantify ecological status [2]. Popular of these indices used for mapping vegetation change dynamics is the Normalized Difference Vegetation Index (NDVI) of Rouse et al. [15] which is a single indicator that has been adopted in a variety of ecological studies [2], [16][18].

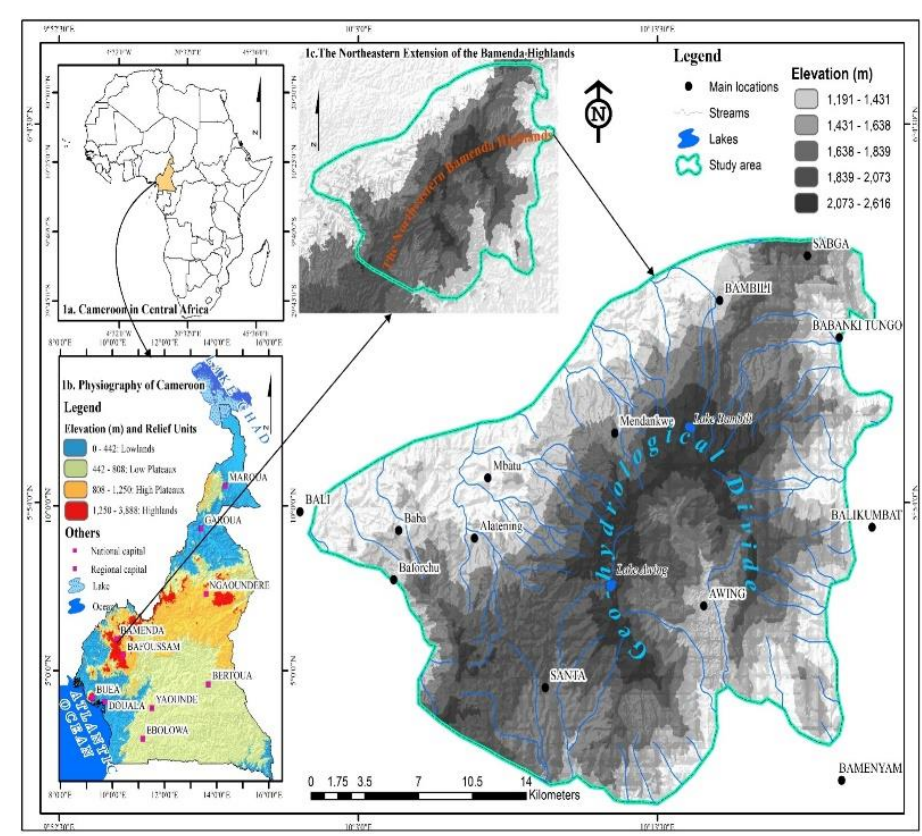

Fig. 1. Location of the study area.

The NDVI represents the vegetation biomass and is expressed as the ratio of near-infrared to red reflection [19]. Vegetation indices are seamless data products that are computed from the same mathematic formulae across all pixels in time and space, without prior assumptions of biome type, land cover condition, or soil type and thus represent actual, long-term measurements of the land surface [20]. Greenness is denoted with NDVI, which is the most commonly used vegetation index in measuring vegetation productivity due to its simplicity and robustness [16]. As a measure of the ecological health of the highlands, the NDVI was estimated over different timescales for a period of 41 years (1979-2020) from multi-sensor imagery.

\section{Image Acquisition and Pre-processing}

The study made use of multi-source remote sensing images. Landsat data products are recommended for monitoring land use/land cover and disturbance, due to their continuous data accessibility free of cost since 1972 [3]. Due to its 60-30 m resolution, Landsat images have often been substituted with high resolution imagery ASTER at $15 \mathrm{~m}$ (Table I) and Sentinel-2 at 10-60 m resolution when smaller study areas are concern. The NDVI is given as:

$$
N D V I=\frac{\rho_{N I R}-\rho_{R}}{\rho_{N I R}+\rho_{R}}
$$

where $\rho$ is the spectral reflectance of the respective spectral bands (red (R)) and near infrared (NIR)) as in Table II. 
TABLE I: REMOTE SENSING DATA USED FOR THE STUDY

\begin{tabular}{cccccc}
\hline S/N & Sensor & $\begin{array}{c}\text { Cell size } \\
(\mathrm{m})\end{array}$ & $\begin{array}{c}\text { Acquisition } \\
\text { Date }\end{array}$ & $\begin{array}{c}\text { Satellite } \\
\text { owner }\end{array}$ & $\begin{array}{c}\text { Data } \\
\text { provider }\end{array}$ \\
\hline 1 & $\begin{array}{c}\text { LANDSAT } 3 \\
\text { (MSS) }\end{array}$ & 60 & $1979 / 12 / 09$ & NASA & USGS \\
2 & $\begin{array}{c}\text { LANDSAT } 5 \\
(\text { TM) }\end{array}$ & 30 & $1988 / 02 / 02$ & NASA & USGS \\
3 & $\begin{array}{c}\text { LANDSAT } 7 \\
(\text { ETM })\end{array}$ & 30 & $2001 / 12 / 31$ & NASA & USGS \\
4 & ASTER & 15 & $2008 / 01 / 31$ & $\begin{array}{c}\text { NASA \& } \\
\text { METI }\end{array}$ & USGS \\
5 & ASTER & 15 & $2015 / 01 / 02$ & $\begin{array}{c}\text { NASA \& } \\
\text { METI }\end{array}$ & USGS \\
6 & ASTER & 15 & $2020 / 03 / 08$ & $\begin{array}{c}\text { NASA \& } \\
\text { METI }\end{array}$ & USGS \\
\hline
\end{tabular}

METI: Ministry of Economy, Trade and Industry, Japan, NASA: National Aeronautics and Space Agency, USGS: US Geological Survey.

TABLE II: LANDSAT BAND CHARACTERISTICS AND NDVI SPECTRAL BANDS USED FOR VEGETATION CHANGE DETECTION.

Landsat 4-5 Thematic Mapper (TM) and Landsat 7 Enhanced Thematic Mapper Plus (ETM+)

\begin{tabular}{|c|c|c|}
\hline \\
\hline Band 1 - blue & $0.45-0.52$ & $\begin{array}{l}\text { Bathymetric mapping, } \\
\text { distinguishing soil from } \\
\text { vegetation and deciduous from } \\
\text { coniferous vegetation }\end{array}$ \\
\hline Band 2 - green & $0.52-0.60$ & $\begin{array}{l}\text { Emphasizes peak vegetation, } \\
\text { which is useful for assessing } \\
\text { plant vigor }\end{array}$ \\
\hline Band 3 - red & $0.63-0.69$ & Discriminates vegetation slopes \\
\hline Band 4 - Near Infrared & $0.77-0.90$ & $\begin{array}{l}\text { Emphasizes biomass content } \\
\text { and shorelines }\end{array}$ \\
\hline $\begin{array}{l}\text { Band } 5 \text { - Short-wave } \\
\text { Infrared }\end{array}$ & $1.55-1.75$ & $\begin{array}{l}\text { Discriminates moisture content } \\
\text { of soil and vegetation; } \\
\text { penetrates thin clouds }\end{array}$ \\
\hline $\begin{array}{l}\text { Band } 6 \text { - Thermal } \\
\text { Infrared }\end{array}$ & $10.40-12.50$ & $\begin{array}{l}\text { Thermal mapping and } \\
\text { estimated soil moisture }\end{array}$ \\
\hline $\begin{array}{l}\text { Band } 7 \text { - Short-wave } \\
\text { Infrared }\end{array}$ & $2.09-2.35$ & $\begin{array}{l}\text { Hydrothermally altered rocks } \\
\text { associated with mineral } \\
\text { deposits }\end{array}$ \\
\hline $\begin{array}{l}\text { Band } 8 \text { - Panchromatic } \\
\text { (Landsat } 7 \text { only) }\end{array}$ & $0.52-0.90$ & $\begin{array}{l}15 \text { meter resolution, sharper } \\
\text { image definition }\end{array}$ \\
\hline \multicolumn{3}{|c|}{ Landsat MSS 1, 2, 3 Spectral Bands } \\
\hline Band 4 - green & $0.5-0.6$ & $\begin{array}{l}\text { Sediment-laden water, } \\
\text { delineates areas of shallow } \\
\text { water }\end{array}$ \\
\hline Band 5 - red & $0.6-0.7$ & Cultural features \\
\hline Band 6 - Near Infrared & $0.7-0.8$ & $\begin{array}{l}\text { Vegetation boundary between } \\
\text { land and water, and landforms }\end{array}$ \\
\hline Band 7 - Near Infrared & $0.8-1.1$ & $\begin{array}{l}\text { Penetrates atmospheric haze } \\
\text { best, emphasizes vegetation, } \\
\text { boundary between land and } \\
\text { water, and landforms }\end{array}$ \\
\hline \multicolumn{3}{|c|}{ Landsat MSS 4, 5 Spectral Bands } \\
\hline Band 1 - green & $0.5-0.6$ & $\begin{array}{l}\text { Sediment-laden water, } \\
\text { delineates areas of shallow } \\
\text { water }\end{array}$ \\
\hline Band $2-$ red & $0.6-0.7$ & Cultural features \\
\hline Band 3 - Near Infrared & $0.7-0.8$ & $\begin{array}{l}\text { Vegetation boundary between } \\
\text { land and water, and landforms }\end{array}$ \\
\hline Band 4 - Near Infrared & $0.8-1.1$ & $\begin{array}{l}\text { Penetrates atmospheric haze } \\
\text { best, emphasizes vegetation, } \\
\text { boundary between land and } \\
\text { water, and landforms }\end{array}$ \\
\hline
\end{tabular}

To compute vegetation and other spectral indices, one needs to convert DN to Top-of-Atmospheric Reflectance (TOA) values. This involves a two-step procedure; conversion of DN to radiance, and later converting radiance to TOA.

Conversions to TOA reflectance were affected for Landsat Thematic Mapper (TM 5) and Landsat Operational Land Imager and Thermal Infrared Sensor (OLI/TIRS) using the DOS 1 atmospheric correction extension in semi- automatic classification plugin version 6.4.7 in QGIS 3.14. With regards to Table II, ASTER VNIR band 2 (red) and VNIR Band $3 \mathrm{~N}$ (near-infrared) at $15 \mathrm{~m}$ resolution were selected to compute NDVI.

NDVI values range from +1.0 to -1.0 . Areas of barren rock, sand, or snow usually show very low NDVI values (for example, 0.1 or less). Sparse vegetation such as shrubs and grasslands or senescing crops may result in moderate NDVI values (approximately 0.2 to 0.5 ). High NDVI values (approximately 0.6 to 0.9 ) correspond to dense vegetation such as that found in temperate and tropical forests or crops at their peak growth stage [21]. The resultant NDVI was reclassified into six classes based on the aforementioned NDVI value-vegetation classification. No vegetation (builtup, water bodies burned surfaces and bare rocks) with NDVI of sparse vegetation (degraded grasslands and farmland), NDVI (0.30-0.40), Savanna grassland (NDVI between 0.40$0.50)$, degraded Montane forest (0.50-0.60) and intact Montane forest (NDVI $=0.60-0.70+$ ).

\section{RESULTS AND DISCUSSIONS}

\section{A. Vegetation Phenological Changes and Ecological Dynamics}

Seasonal changes and humanization have had an impact on vegetation dynamics of the watershed. Montane forest in 1979 represents the greatest plant vigour and maximum productivity indicated by its NDVI $=1$ comparatively with 2008 (NDVI=0.91). Despite the late 1990s as assessed in 2001, montane forest health has been relatively stable over the 41 year period (see NDVI for 1988, 2015, 2020) (Table III). This healthy vegetation it is largely promoted by eucalyptus colonization of the watershed. Some natural regrowth has been observed and quantified especially with gallery forest.

The progressive decline in NDVI for very low grassland vegetation is indicative of unsustainable grazing and settlement related activities. The progress in health of sparse vegetation is also and indicative of increase conversion of shrub savanna and degraded montane forest to grassland. This slight increase in health of degraded montane forest is suggestive of natural forest regrowth (Table III and Fig. 27). This explains vegetation greening and browning trends linked mostly to anthropogenic stressors on the highlands (Fig. 8).

TABLE III: ESTIMATED NDVI VALUES FOR DIFFERENT CLASSES OF LAND COVER OVER 41 YEARS

\begin{tabular}{ccccccc}
\multicolumn{7}{c}{ COVER OVER 41 YEARS } \\
\hline $\begin{array}{c}\text { Ecology/vegetation } \\
\text { cover type }\end{array}$ & 1979 & 1988 & 2001 & 2008 & 2015 & 2020 \\
\hline $\begin{array}{c}\text { No vegetation } \\
\text { Very low vegetation } \\
\quad-0.87\end{array}$ & -0.76 & -0.04 & -0.29 & -0.00 & -0.07 \\
$\begin{array}{c}\text { (degraded) } \\
\text { Sparse vegetation } \\
\quad \text { (grassland) }\end{array}$ & 0.33 & 0.39 & 0.35 & 0.44 & 0.49 & 0.52 \\
$\begin{array}{c}\text { Moderate vegetation } \\
\quad \text { (savanna) }\end{array}$ & 0.4 & 0.4 & 0.4 & 0.54 & 0.58 & 0.6 \\
$\begin{array}{c}\text { Degraded montane } \\
\text { forest }\end{array}$ & 0.5 & 0.62 & 0.46 & 0.65 & 0.68 & 0.69 \\
Montane forest & 1 & 0.87 & 0.66 & 0.91 & 0.89 & 0.87 \\
\hline
\end{tabular}

\section{B. Areal Variation in Landscape Ecology}

Montane forest area varied; 9423ha in 1979, 7066.35 ha in 1988, 8253.09 ha in 2001, 6221.53 ha in 2008, 8621.49 ha in 2015 and 12931.56 ha in 2020 (Table IV). 


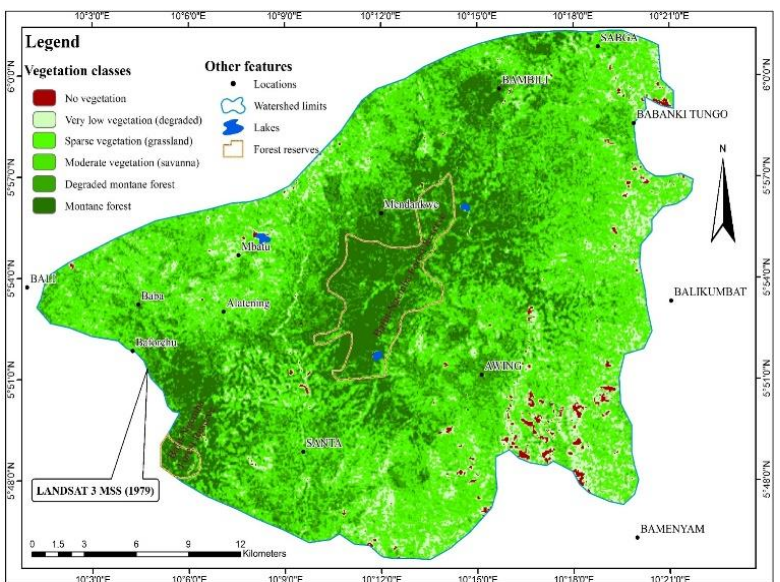

Fig. 2. Highland green cover index in 1979.

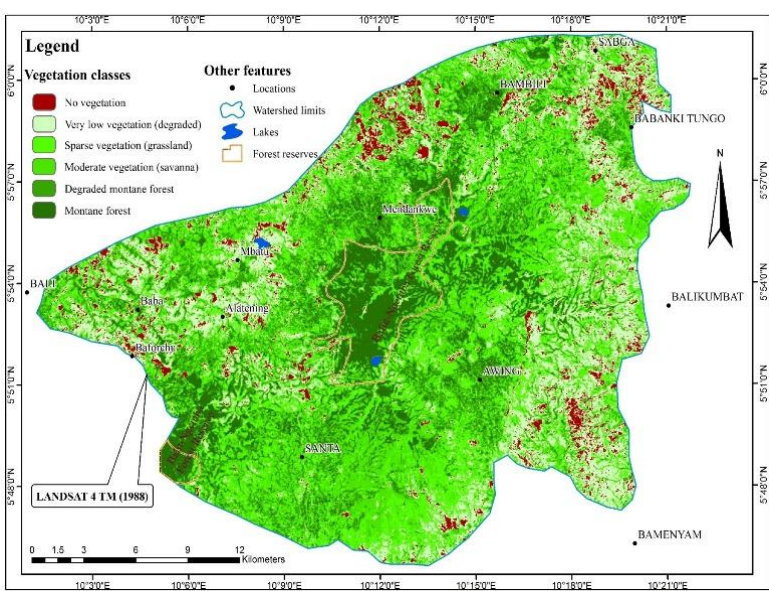

Fig. 3. Highland green cover index in 1988.

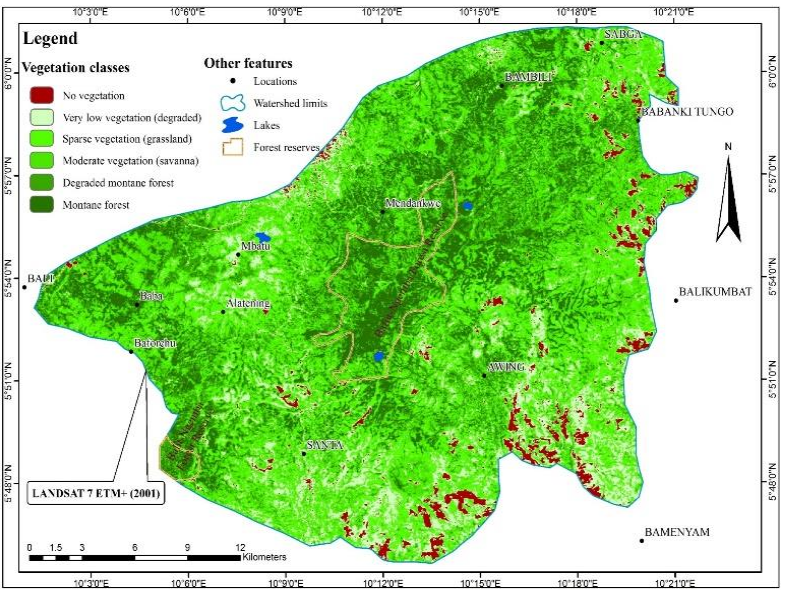

Fig. 4. Highland green cover index in 2001.

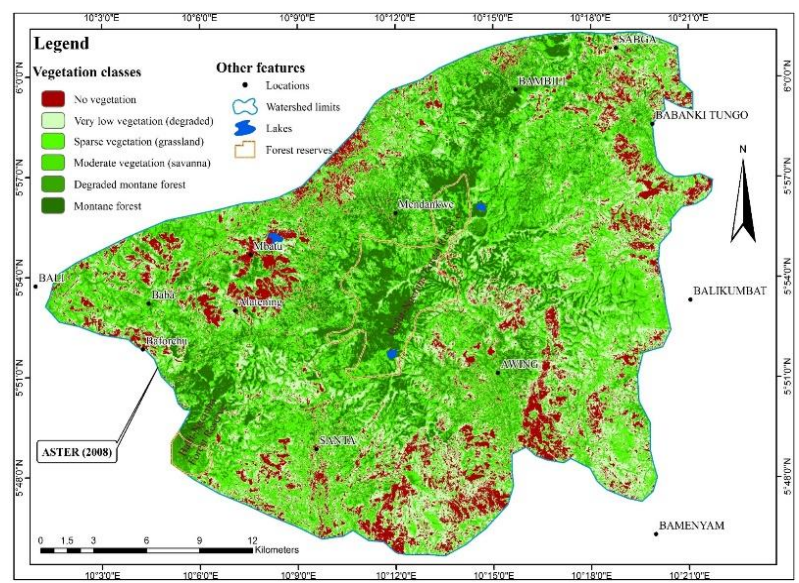

Fig. 5. Highland green cover index in 2008.

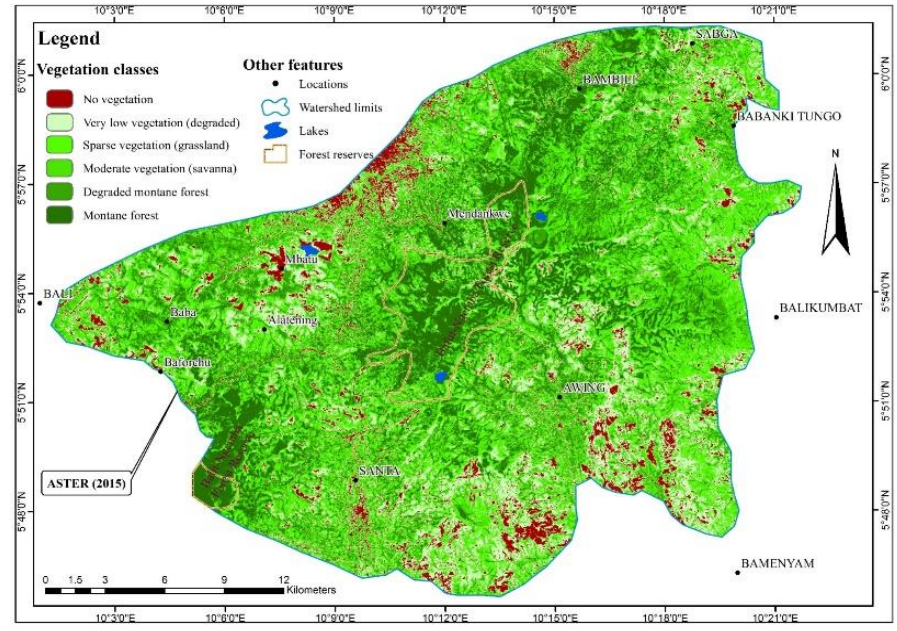

Fig. 6. Highland green cover index in 2015

Of great dynamism and importance is forest.

The cumulative gain in montane forest area between 2008-2020 either 2399.96 (2008-2015) and 4310.07 ha (2015-2020) is linked to two things; progressive replacement of natural vegetation with fast money yielding eucalyptus and natural regrowth of gallery forest in less accessible steep slopes on the highlands around the vicinity of Awing (Table IV, Fig. 7).

In a bit to conserve the rich montane forest and biodiversity of the Bamenda Highlands, forest reserves were created way back in the colonial era. These are the BafutNgemba and Bali-Ngemba forest Reserves (Fig. 7). Rather than being save havens for the threatened biodiversity, these forest reserves have been depleted of their natural landscapes by continuous unsustainable exploitation of their forest resources. At present, the Bafut-Ngemba is ecological refugia. This has been reported by several authors [22]-[24]. The Bafut-Ngemba Forest Reserve is a deforestation hotspot as shown (Fig. 7). Despite the unsuitable greening of the highlands with environmentally unfriendly water demanding eucalyptus, some blueprints are observed for the highlands. The progressive regrowth of gallery forest on inaccessible slopes. This implies that if sustainable exploitation of resources is implemented, there will be increase greenness of the highlands, alongside an increase water supply, food, fiber and other ecological services pertaining to highland areas.

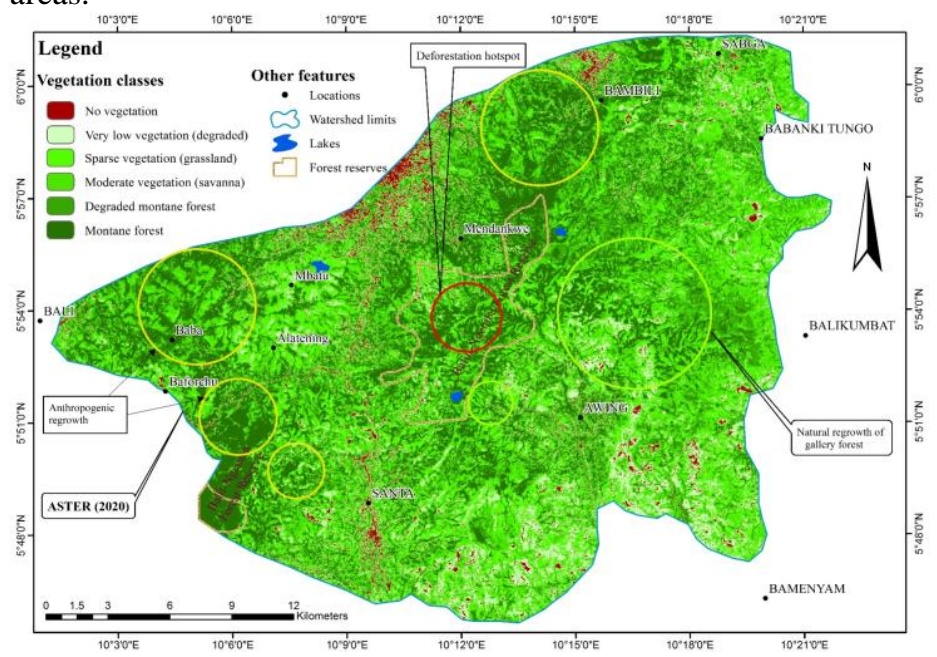

Fig. 7. Highland green cover index in 2020 showing deforestation hotspots, anthropogenic and natural regrowth. 
TABLE IV: VEGETATION CHANGE/DYNAMICS STATISTICS FOR NORTHEASTERN BAMENDA HigHLANDS (1979-2020)

\begin{tabular}{|c|c|c|c|c|c|c|c|c|c|c|c|}
\hline Vegetation types & 1979 & 1988 & 2001 & 2008 & 2015 & 2020 & 1979-1988 & $1988-2001$ & $2001-2008$ & $2008-2015$ & $2015-2020$ \\
\hline No vegetation & 545.76 & 3431.88 & 1948.77 & 7973.37 & 4024.12 & 1907.46 & 2886.12 & -1483.11 & 6024.6 & -3949.25 & 978.66 \\
\hline $\begin{array}{c}\text { Very low vegetation } \\
\text { (degraded) }\end{array}$ & 5832 & 13997.25 & 7757.19 & 15821.73 & 11353.52 & 6738.57 & 8165.25 & -6240.06 & 8064.54 & -4468.21 & -1128.61 \\
\hline $\begin{array}{l}\text { Sparse vegetation } \\
\text { (grassland) }\end{array}$ & 15629.76 & 15707.61 & 15645.87 & 14614.27 & 14331.91 & 12963.26 & 77.85 & -61.74 & -1031.6 & -282.36 & -1368.65 \\
\hline $\begin{array}{l}\text { Moderate vegetation } \\
\text { (savanna) }\end{array}$ & 19171.8 & 13895.46 & 17576.64 & 11452.28 & 14342.23 & 15638.88 & -5276.34 & 3681.18 & -6124.36 & 2889.95 & 1296.65 \\
\hline $\begin{array}{l}\text { Degraded montane } \\
\text { forest }\end{array}$ & 14830.56 & 11334.33 & 14251.32 & 9349.7 & 12759.61 & 15253.15 & -3496.23 & 2916.99 & -4901.62 & 3409.91 & 2493.54 \\
\hline $\begin{array}{c}\text { Montane forest } \\
\text { Total }\end{array}$ & $\begin{array}{c}9423 \\
65432.88\end{array}$ & $\begin{array}{c}7066.35 \\
65432.88\end{array}$ & $\begin{array}{c}8253.09 \\
65432.88\end{array}$ & $\begin{array}{c}6221.53 \\
65432.88\end{array}$ & $\begin{array}{c}8621.49 \\
65432.88\end{array}$ & $\begin{array}{l}12931.56 \\
65432.88\end{array}$ & $\begin{array}{c}-2356.65 \\
-\end{array}$ & $\begin{array}{c}1186.74 \\
-\end{array}$ & $\begin{array}{c}-2031.56 \\
-\end{array}$ & $\begin{array}{c}2399.96 \\
-\end{array}$ & $\begin{array}{c}4310.07 \\
-\end{array}$ \\
\hline
\end{tabular}

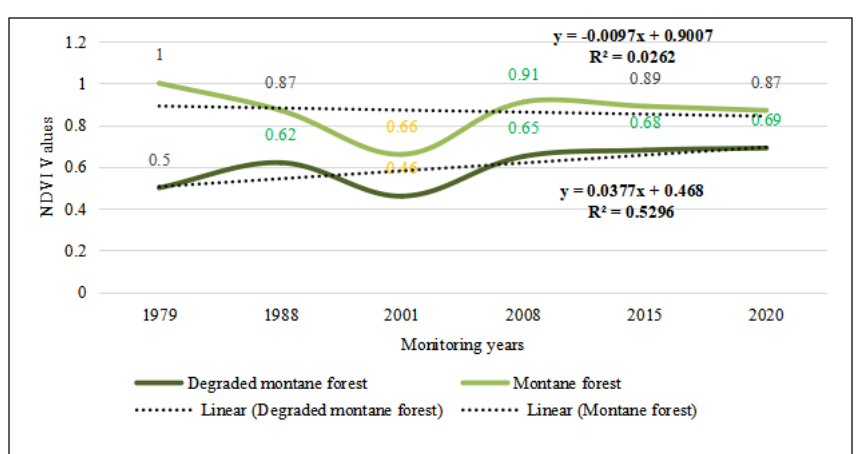

Fig. 8. Forest greening and browning trends on the highlands (1979-2020).

Greening trends for degraded montane and montane forest were observed in 1988 (montane forest), 2008 (montane forest and degraded montane forest), 2015-2020 (degraded montane forest). The increase greening of montane forest is linked to increase colonization of the highlands by early maturing eucalyptus plantations (Fig. 7 and 8).

Browning trends were witnessed in 2001 demonstrated by 0.46 and 0.66 NDVI values for degraded and montane forest respectively. Deforestation was alarming between 1979 and 1988 (either -2356.65ha of forest loss) and 2001-2008 (either -2031.56ha of forest loss).

This deforestation includes the harvest of stands of eucalyptus plantations as well of natural montane forest (see Fig. 4) the northwestern section of the study area) to serve the fuel wood needs of the nearby settled communities. The commercialization of eucalyptus firewood along the Babadjou-Bafoussam Highway precisely at Santa is commonplace today.

\section{CONCLUSIONS AND RECOMMENDATIONS}

Remotely sensed imagery through advance space technology is constantly serving humanity in the mastery of landscape dynamics triggers. From the analysis uncovered in this piece of research it is evident that knowledge regarding ecological change detection in the Northeastern Bamenda highlands using the NDVI (1979-2020) is being strengthened and hence very useful to stakeholders. Notwithstanding other ecological damaging techniques, the commercialization of eucalyptus fuel wood is a livelihood improvement strategy that has proven its limitations. This therefore requires more sustainable landscape management techniques by stakeholders. The study recommends a massive recolonization of degraded landscapes with multipurpose tree spices such as Azadirachta Indica (Neem) Moringa Oleifera (Moringa), Gliricidia Sepium (Gliricodia). Secondly, the Bafut -Ngemba reserve should be extended in surface area. The Mincipalities of Santa, Bamenda I, II, III, Bafut and Tubah should allocate some council funds for advance research in sustainable landscape restoration strategies.

\section{REFERENCES}

[1] E.F. Lambin, and A. H. Strahlers, 'Change-vector analysis in multitemporal space: a tool to detect and categorize land-cover change processes using high temporal-resolution satellite data', Remote Sensing of Environment, Vol. 48, No. 2, pp. 231-244, 1994.

[2] H. Xu, Y. Wang, H. Guan, T. Shi, X. Hu, 'Detecting Ecological Changes with a Remote Sensing Based Ecological Index (RSEI) Produced Time Series and Change Vector Analysis'. Remote Sensing 11, 2345, 2019. https://doi.org/10.3390/rs11202345.

[3] K. S. Willis, 'Remote sensing change detection for ecological monitoring in United States protected areas'. Biological Conservation, 182: 233-242, 2015. DOI: 10.1016/j.biocon.2014.12.006.

[4] R. S. Lunetta, J. F. Knight, J. Ediriwickrema, J. G. Lyon, and L. D. Worthy, 'Land-cover change detection using multi-temporal MODIS NDVI data'. Presented at International Symposium on Remote Sensing of Environment, San Jose, COSTA RICA, June 25 - 29 , 2007.

[5] R. E. Kennedy, P. A. Townsend, J. E. Gross, W. B. Cohen, P. Bolstad, Y.Q. Wang, P. Adams, 'Remote sensing change detection tools for natural resource managers: Understanding concepts and tradeoffs in the design of landscape monitoring projects'. Remote Sensing of Environment, 113, 1382-1396, 2009.

[6] XIAO, X. M., ZHANG, Q.; BRASWELL, B. Modeling gross primary production of temperate deciduous broadleaf forest using satellite images and climate data. Remote Sensing of Environment, n.91, 2004, p. 256-270.

[7] Xie, Y. Remote sensing imagery in vegetation mapping: A review. Journal of Plant Ecology, 1(1), 2008, p.9-23. doi: 10.1093/jpe/rtm005.

[8] Ahmad, F. (2012). Detection of change in vegetation cover using multi-spectral and multi-temporal information for district Sargodha, Pakistan. Sociedade \& Natureza, 24(3), 557-572.

[9] United Nations (Online). Mountains - related SDGs. https://sdgs.un.org/topics/mountains.

[10] FAO (2017). Mountains and sustainable development goals. http://www.fao.org/fileadmin/templates/mountain_partnership/doc/M ountains_and_the_SDGs.pdf.

[11] Gratzer, G. and Keeton, S. W. (2017). Mountain Forests and Sustainable Development: The Potential for Achieving the United Nations' 2030 Agenda. Mountain Research and Development, 37(3): 246-253. https://doi.org/10.1659/MRD-JOURNAL-D-17-00093.1

[12] UNECE (2019). Mountain Green Cover Index (SDG Indicator 15.4.2).

https://unece.org/fileadmin/DAM/stats/documents/ece/ces/ge.33/2019 /mtg2/S4_3_Ind_15_4_2_MountainGreenCoverIndex_EN.pdf.

[13] Paegelow M., Camacho M.O., Ferraty F., Ferré L., Sarda P., Villa N. (2008) Prospective modelling of environmental dynamics: A methodological comparison applied to mountain land cover changes. In: Paegelow M., Olmedo M.T.C. (eds) Modelling Environmental Dynamics. Environmental Science and Engineering (Environmental Science). Springer, Berlin, Heidelberg. https://doi.org/10.1007/978-3540-68498-5_5.

[14] Aly, A. A., Al-Omran, A. M., Sallam, A. S., Al-Wabel, M. I., AlShayaa, M. S. (2016). Vegetation cover change detection and assessment in arid environment using multi-temporal remote sensing images and ecosystem management approach. Solid Earth, 7, 713725. doi:10.5194/se-7-713-2016.

[15] Rouse, J.W.; Haas, R.H.; Schell, J. A.; Deering, D.W. Monitoring vegetation systems in the Great Plains with ERTS. Third ERTS Symposium, Proceedings... NASA SP-351 I: 309-317. 1973.

[16] Mishra, N.B.; Crews, K.A.; Thoralf, N.M.; Kenneth, R.Y. MODIS derived vegetation greenness trends in African Savanna: 
Deconstructing and localizing the role of changing moisture availability, fire regime and anthropogenic impact. Remote Sens. Environ. 2015, 169, 192-204.

[17] White, D.C.; Lewis, M.M.; Green, G.; Gotch, T.B. A generalizable NDVI-based wetland delineation indicator for remote monitoring of groundwater flows in the Australian Great Artesian Basin. Ecol. Indic. 2016, 60, 1309-1320.

[18] Dubinin, V.; Svoray, T.; Dorman, M.; Perevolotsky, A. Detecting biodiversity refugia using remotely sensed data. Landsc. Ecol. 2018, 33, 1815-1830.

[19] Tucker, C. J. Red and photographic infrared linear combinations for monitoring vegetation. Remote Sensing of Environment, n.8, 1979, p.127-150.

[20] Huete, A. R, Didan, K., Miura, T. Overview of the radiometric and biophysical performance of the MODIS vegetation indices. Remote Sensing of Environment, n.83, 2002, p. 195-213.

[21] USGS (online). NDVI, the Foundation for Remote Sensing Phenology. https://www.usgs.gov/landresources/eros/phenology/science/ndvi-foundation-remote-sensingphenology?qt-science_center_objects=0\#qt-science_center_objects (accessed on the 13th May 2020).

[22] Takem-Mbi, B. M. (2013). Assessing forest cover change in the Bafut-Ngemba Forest Reserve (BNFR), North West Region of Cameroon using remote sensing and GIS. International Journal of Agricultural Policy and Research, 1 (7), 180-187.

[23] Fogwe, Z. N., Tume, S. J. P., Fouda, M. (2019). Eucalyptus Tree Colonization of the Bafut-Ngemba Forest Reserve, North West Region, Cameroon. Environment \& Ecosystem Science, 3 (2), 12-16.
[24] J. A. Maghah, R. M. Fokeng, The Degradation of the Bafut-Ngemba Forest Reserve Revisited: A Spatio-temporal Analysis of Forest Cover Change Dynamics, American Journal of Remote Sensing. Vol. 9, No. 1, 2021, pp. 33-41. doi: 10.11648/j.ajrs.20210901.14.

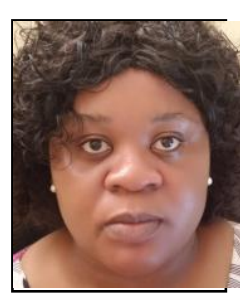

Josephine A. Maghah holds a B.Sc degree in Sociology from the University of Buea, Cameroon, and an M.A degree in African Studies from the University of Free State, South Africa. She is currently an Assistant Lecturer in the Department of Communication and Development Studies, The University of Bamenda, Cameroon. The courses that she teaches are Development Studies, Public Health and Development, Environment and Development, and Climate Change and Development. She is currently completing a Ph.D. is Landscape Ecology and Watershed Management in the Department of Geography and Planning of The University of Bamenda. Her current research interests revolve around ecological modelling, climate and environmental variability, and development nexus. Aside from teaching and research, she holds the administrative position of Faculty Officer of the Faculty of Arts of The University of Bamenda. 